\section{Catalytic Intramolecular C-H Alkylation for the Synthesis of Peptide Macrocycles}
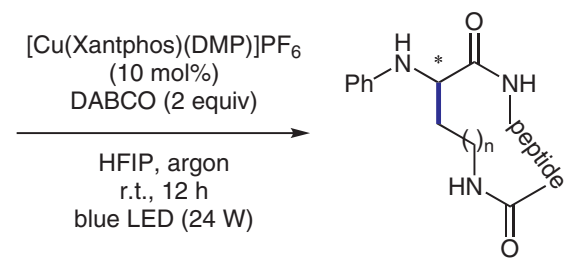

Selected examples:

\section{Key words}

photocatalysis

copper catalysis

iridium catalysis

peptide macrocycles

C-H alkylation

macrocyclization<smiles>O=C(NCCCCCC(Nc1ccccc1)C(=O)N1CCCC1)C1CCCCC1</smiles><smiles>CCCCNC(=O)[C@H](C)NC(=O)[C@@H]1CCCN1C(=O)[C@H](C)Nc1ccccc1</smiles><smiles>CCCC(NC(=O)[C@@H]1CCCN1C(=O)C(CCCCCNC(=O)CC)Nc1ccccc1)C(C)C</smiles>

$52 \%$ yield, $d r=10: 1$

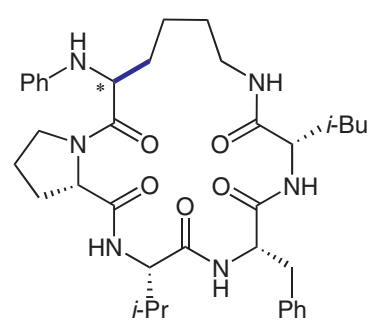

$34 \%$ yield, $d r>20: 1$

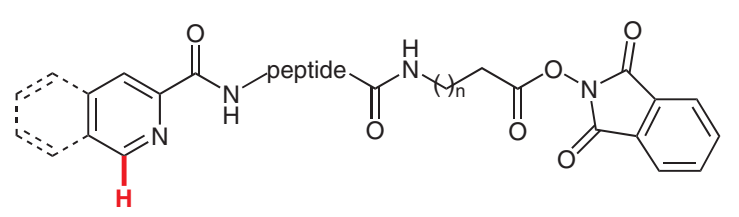

$\left[\operatorname{lr}\left(\mathrm{dF}\left(\mathrm{CF}_{3}\right) \mathrm{ppy}\right)_{2}(\mathrm{dtbpy})\right] \mathrm{PF} 6$ $(2 \mathrm{~mol} \%)$
BINOL phospholic acid
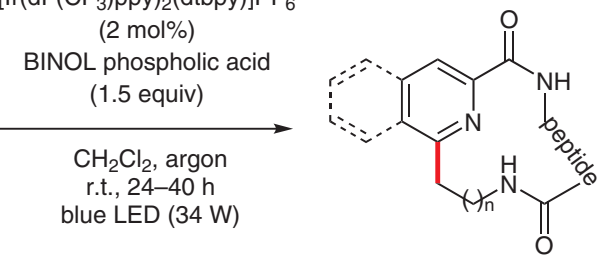

Selected examples:<smiles>CC(C)C(=O)N1CCC[C@H]1C(=O)NCCCCCc1nc(C(=O)N[C@@H](C)C(=O)N[C@@H](C(=O)c2ccccc2)C(C)(C)C)cc2ccccc12</smiles>

$55 \%$ yield<smiles>CC(C)[C@@H](C)C(=O)NCc1nc(C(=O)N[C@H]2NC(=O)[C@@H](C(C)C)NC2=O)cc2ccccc12</smiles>

$50 \%$ yield<smiles></smiles>

$58 \%$ yield
Significance: Peptide macrocycles provide an important platform for drug discovery. The authors have developed intramolecular $\mathrm{C}-\mathrm{H}$ alkylations under blue LED irradiation for the macrocyclization of peptides.
Comment: Copper- or iridium-catalyzed intramolecular C-H alkylations were successfully promoted by blue LED irradiation. The desired peptide macrocycles were obtained in moderate yields. 